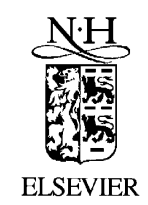

\title{
Investor protection and equity markets
}

\author{
Andrei Shleifer ${ }^{\mathrm{a}, *}$, Daniel Wolfenzon ${ }^{\mathrm{b}}$ \\ ${ }^{a}$ Littauer Center Department of Economics, Harvard University, Cambridge, MA 02138, USA \\ ${ }^{\mathrm{b}}$ New York University, New York, NY 10012, USA
}

Received 4 October 2000; accepted 7 December 2001

\begin{abstract}
We present a simple model of an entrepreneur going public in an environment with poor legal protection of outside shareholders. The model incorporates elements of Becker's (J. Political Econ. 106 (1968) 172) "crime and punishment" framework into a corporate finance environment of Jensen and Meckling (J. Financial Econ. 3 (1976) 305). We examine the entrepreneur's decision and the market equilibrium. The model is consistent with a number of empirical regularities concerning the relation between investor protection and corporate finance. It also sheds light on the patterns of capital flows between rich and poor countries and on the politics of reform of investor protection.
\end{abstract}

(C) 2002 Elsevier Science B.V. All rights reserved.

JEL classification: G31; G32

Keywords: Investor protection; Ownership structure; Financial systems

\section{Introduction}

Recent research reveals that a number of important differences in financial systems among countries are shaped by the extent of legal protection afforded outside investors from expropriation by the controlling shareholders or managers. The findings show that better legal protection of outside shareholders is associated with: (1) more valuable stock markets (La Porta et al., 1997); (2) a higher number of

\footnotetext{
${ }^{\star 2}$ We are grateful to Edward Glaeser, Simon Johnson, Rafael La Porta, Florencio Lopez-de-Silanes, David Scharfstein, Erik Sirri, and two anonymous referees for helpful comments and the NSF for financial support of this research.

${ }^{*}$ Corresponding author. Tel.: + 1-617-495-5046; fax: + 1-617-496-1708.

E-mail address: ashleifer@harvard.edu (A. Shleifer).
} 
listed firms (La Porta et al., 1997); (3) larger listed firms in terms of their sales or assets (Kumar et al., 1999); (4) higher valuation of listed firms relative to their assets (Claessens et al., 2002; La Porta et al., 2002); (5) greater dividend payouts (La Porta et al., 2000a); (6) lower concentration of ownership and control (European Corporate Governance Network, 1997; La Porta et al., 1999; Claessens et al., 2000); (7) lower private benefits of control (Zingales, 1994; Nenova, 1999); and (8) higher correlation between investment opportunities and actual investments (Wurgler, 2000).

While the understanding of the empirical differences in the patterns of corporate finance has advanced considerably, the theoretical work in this area is only beginning. A number of studies explicitly model the expropriation of minority shareholders by the controlling shareholders (see, among others, Grossman and Hart, 1988; Harris and Raviv, 1988; Hart, 1995; Burkart et al., 1997, 1998; Friedman and Johnson, 2000) and the legal framework underlining such expropriation (La Porta et al., 1998; Johnson et al., 2000). Other studies attempt to explain theoretically why control is so concentrated in countries with poor shareholder protection (Zingales, 1995; La Porta et al., 1999; Bebchuk, 1999), and why such organizational form as pyramids may be common (Wolfenzon, 1999). Still other studies, such as Bennedsen and Wolfenzon (2000), argue that control structures with multiple large shareholders may be efficient in environments with poor shareholder protection. La Porta et al. (2002) make the case for higher concentration of cash flow ownership (and not just control) in countries with poor shareholder protection. Each of these studies has focused on specific aspects of legal environments with weak shareholder protection. But a market equilibrium model of corporate finance in such environments remains to be developed. ${ }^{1}$

In this paper we present one such model. The model incorporates elements of Becker's (1968) classic "crime and punishment" framework into a corporate finance environment as in Jensen and Meckling (1976). We consider an entrepreneur trying to raise equity finance for a project, and deciding how much equity to sell and how big a project to undertake. We follow the literature (Zingales, 1995; Bebchuk, 1999) in maintaining that the entrepreneur keeps control of the project after the initial share offering. This entrepreneur operates in an environment with limited legal protection of outside shareholders, and so has an opportunity to divert some of the profits of the firm once they materialize (Shleifer and Vishny, 1997; Burkart et al., 1998). By doing so, he risks being sued and fined for breaking the law or the shareholder agreement. The quality of investor protection in our model is given by the likelihood that the entrepreneur is caught and fined for expropriating from shareholders.

In this simple model, we show how the entrepreneur's decisions on the size of the project and the amount of cash flow to sell are shaped by the legal environment. We then embed this going-public decision into a market equilibrium with savers and

\footnotetext{
${ }^{1}$ One strand of the empirical literature not discussed in this paper deals with the implications of investor protection for economic growth. On this, see Carlin and Mayer (1999), Demirguc-Kunt and Maksimovic (1998), Levine and Zervos (1998), and Rajan and Zingales (1998).
} 
firms, and consider the determination of the size of the capital market. We consider both the case of the worldwide capital market and that of segmented national markets.

Under plausible conditions, this model generates a number of predictions. Firms are larger, more valuable, and more plentiful, dividends are higher (and diversion of profits lower), ownership concentration is lower, and stock markets are more developed in countries with better protection of shareholders. In fact, the simple model delivers results corresponding to all eight findings summarized above.

We then go on to apply the model to flows of funds between rich and poor countries. The model explains why such flows are limited, consistent with empirical evidence discussed by Lucas (1990). The model also generates predictions about the welfare effects of improvements in investor protection. In particular, it predicts that entrepreneurs gain more (or lose less) from an improvement in investor protection when the country is open to world capital flows than when it is not. This result is consistent with evidence that openness is correlated with financial development (Rajan and Zingales, 2001). Entrepreneurs are more likely to use their political influence to improve investor protection when the country is open to capital flows.

The next section presents the model. Section 3 describes the demand and supply of funds. The equilibrium is described in Section 4. Section 5 presents an extension of the model to analyze the magnitude of the capital flows from rich to poor countries. Section 6 analyzes the welfare effects from an improvement in investor protection. Proofs are relegated to the appendix.

\section{The model}

Consider a world with $C$ countries, each one populated by $J$ risk-neutral entrepreneurs. Each entrepreneur, $E^{j, c}$ (entrepreneur $j$ from country $c$ ), can develop a project by setting up a firm. Entrepreneurs differ in their initial wealth, $W_{1}^{j, c}$, and in the productivity of their projects, $g^{j, c}$. Since the focus of the paper is on the effect of investor protection, we assume that all countries have an identical pool of entrepreneurs, i.e., for all $j$, and any two countries $c_{1}$ and $c_{2}, W_{1}^{j, c_{1}}=W_{1}^{j, c_{2}}$ and $g^{j, c_{1}}=g^{j, c_{2}}$.

The model has two dates. At date 1, each entrepreneur chooses whether to set up a firm. Firms have two sources of finance. First, from his date 1 wealth, each entrepreneur, $E^{j, c}$, contributes $R_{E}^{j, c} \leqslant W_{1}^{j, c}$ to the firm. He invests his remaining wealth in the market. Second, $E^{j, c}$ raises $R_{M}^{j, c}$ from the market by selling a fraction $x^{j, c}$ of the firm's cash flow rights. We assume that entrepreneurs retain control of their firms regardless of the fraction of the cash flow rights they sell. Each firm uses the funds committed to it to invest $I^{j, c} \leqslant R_{E}^{j, c}+R_{M}^{j, c}$ in the project, and the remaining $R_{E}^{j, c}+R_{M}^{j, c}-I^{j, c}$ in the market.

The market interest rate for country $c, i^{c}$, is determined by the supply and demand for funds. The demand for funds is generated by the individual firms' demand, and the supply of funds is generated by entrepreneurs and firms' supply. We consider two cases. In the first, there is perfect capital mobility and the world's supply and demand 
schedules determine the common interest rate. In the second, there is no capital mobility and each country's interest rate is determined by its own demand and supply schedules.

Revenue is realized at date 2 . The production function exhibits constant returns to scale: every dollar invested in the project generates $1+g^{j, c}$ dollars. The date 2 revenue of the firm, $\Pi^{j, c}$, is then given by

$$
\Pi^{j, c}=\left(1+g^{j, c}\right) I^{j, c}+\left(1+i^{c}\right)\left(R_{M}^{j, c}+R_{E}^{j, c}-I_{M}^{j, c}\right) .
$$

The entrepreneur chooses the fraction $d^{j, c}$ of the revenue he diverts. We assume that the levels of legal protection afforded to minority shareholders vary across countries. Following Becker (1968), we assume that the entrepreneur is caught with probability $k^{c} \in[0,1]$, where the parameter $k^{c}$ is a measure of the legal protection of investors in country $c$. Higher values of $k^{c}$ correspond to better investor protection.

An alternative assumption might be that firms in the same country but in different industries are subject to different levels of investor protection. For example, the level of investor protection could be higher for regulated firms. A different assumption might be that ownership structure affects the level of investor protection. A firm with a second large shareholder could have a higher effective investor protection level, since the other large shareholder's monitoring increases the probability that the entrepreneur is caught (Bennedsen and Wolfenzon, 2000; La Porta et al., 1999; Pagano and Roel, 1998). To keep the model simple, we assume that the level of investor protection, $k^{c}$, is the same for all firms in a country and does not depend on the ownership structure.

If the entrepreneur is caught, he is forced to return the diverted amount to the firm and, in addition, to pay a fine of $f\left(d^{j, c}\right) \Pi^{j, c}$ to the authorities. ${ }^{2}$ In this case, the entire revenue is distributed as dividends. However, if the entrepreneur is not caught, he keeps the entire diverted amount, and the fraction of the revenue not diverted, ( $1-$ $\left.d^{j, c}\right) \Pi^{j, c}$, is distributed as dividends. The entrepreneur's payoff at date 2 is given by

$$
\begin{aligned}
& k^{c}\left[\left(1-x^{j, c}\right) \Pi^{j, c}-f\left(d^{j, c}\right) \Pi^{j, c}\right]+\left(1-k^{c}\right)\left[\left(1-x^{j, c}\right)\left(1-d^{j, c}\right) \Pi^{j, c}+d^{j, c} \Pi^{j, c}\right] \\
& \quad+\left(1+i^{c}\right)\left(W_{1}^{j, c}-R_{E}^{j, c}\right) .
\end{aligned}
$$

Rearranging this expression yields

$$
\begin{aligned}
& \left(1-x^{j, c}\right)\left(1-\left(1-k^{c}\right) d^{j, c}\right) \Pi^{j, c}+\left(1-k^{c}\right) d^{j, c} \Pi^{j, c}-k^{c} f\left(d^{j, c}\right) \Pi^{j, c} \\
& \quad+\left(1+i^{c}\right)\left(W_{1}^{j, c}-R_{E}^{j, c}\right) .
\end{aligned}
$$

Because the entrepreneur keeps the diverted amount with probability $1-k^{c}$, $\left(1-k^{c}\right) d^{j, c} \Pi^{j, c}$ is the expected diversion and $\left(1-\left(1-k^{c}\right) d^{j, c}\right) \Pi^{j, c}$ is the expected dividend.

Finally, we make the following assumption.

\footnotetext{
${ }^{2} \mathrm{We}$ assume that the fine depends on the total amount diverted and not on the amount diverted from minority shareholders. The entrepreneur diverts $d \Pi$ from the corporation - a separate legal person distinct from the legal personalities of its shareholders. Most legal systems would consider the penalty based on the damage done to the corporation, that is the full $d \Pi$. This formulation also guarantees that the agency problem is independent of the size of the project.
} 
Assumption. The function $f(\cdot)$ satisfies

(a) $f(0)=0$,

(b) $f^{\prime}(0)=0$,

(c) $f^{\prime \prime}(d)>0$, and

(d) $\partial\left[f^{\prime}(d) / f^{\prime \prime}(d)\right] / \partial d>0$.

No fine is incurred when diversion is zero (assumption (a)), and the fine is essentially zero for the first cent diverted (assumption (b)). Assumption (c) implies that the marginal fine increases with the amount diverted. Assumption (d) sets a bound on the speed at which $f^{\prime \prime}(d)$ increases. That is, we allow $f^{\prime \prime}(d)$ to be decreasing, constant, or even increasing, as long as it does not increase too fast. ${ }^{3}$ In particular, this assumption eliminates the "boil them in oil" results, in which expropriation is precluded entirely with sufficiently heavy penalties even when the probability of detection is low. Extremely heavy civil penalties are uncommon in most countries for many reasons, including fairness, wealth constraints, the possibility of false convictions, and the risk of subversion of justice by powerful defendants facing exorbitant fines.

\section{The demand and supply of funds}

In this section we take the interest rate $i^{c}$ as given and analyze the choices of an entrepreneur. From the individual choices, we derive the aggregate demand and supply schedules for each level of interest rate $i^{c}$.

We show that entrepreneurs with productivity of projects below $i^{c}$ do not set up firms and instead supply their entire wealth to the market. For any interest rate, $i^{c}$, the aggregate supply of funds is then the aggregate wealth of entrepreneurs with $g^{j, c}<i^{c}$. We also show that entrepreneurs who do not supply their wealth to the market (i.e., those with $g^{j, c} \geqslant i^{c}$ ) invest their entire wealth in their firms and demand additional funds from the market. The aggregate demand for funds is the sum of their individual demands, and measures the desired level of external finance for a given $i^{c}$. We show that, with better investor protection, the desired level of external finance is higher at each $i^{c}$. At the equilibrium interest rate (discussed in the following section), the desired level of external finance and the supply of funds are equalized.

We start solving the model at date 2. To lighten notation, we suppress the superscripts in all variables. At date $2, E$ chooses the level of diversion to maximize his payoff:

$$
\max _{d}\{(1-x)(1-(1-k) d)+(1-k) d-k f(d)\} \Pi+(1+i)\left(W_{1}-R_{E}\right) .
$$

\footnotetext{
${ }^{3}$ The results of the model hold if the fine $f(d, k)$ and the probability of detection $p(d, k)$ depend on both the amount diverted and the level of investor protection. In fact, we could have a more general model in which the entrepreneur diverts $d \Pi$ of the firm and receives private benefits of $(d-c(d, k)) \Pi$, where $c(d, k)$ is the cost of diversion. If $c(d, k)=g(k) f(d)$, and $g^{\prime}(k)>0$ (better investor protection implies higher cost of diversion), we obtain all the results under assumptions (a)-(d). There is no loss of generality in using this simplified setting.
} 
The optimal diversion level $d^{*}(x, k)$ satisfies the following first-order condition:

$$
k f^{\prime}\left(d^{*}\right)=(1-k) x \text {. }
$$

Assumption (c) guarantees that the second-order conditions for a maximum are satisfied. From the viewpoint of the entrepreneur, the left-hand side of Eq. (3) is the marginal cost of diverting, or the marginal increase in the expected fine. For the next dollar diverted, the fine increases by $f^{\prime}(d)$ and he pays this fine with probability $k$. The right-hand side is the marginal benefit of diverting, or the marginal increase in expected dividend savings. By diverting an extra dollar, the entrepreneur avoids paying a fraction $x$ of it to outside shareholders, although he keeps this dollar only with probability $1-k$.

Proposition 1. Suppose that assumptions (a)-(c) hold. The solution to Eq. (3), $d^{*}(x, k)$, satisfies

(a) $d^{*}(0, k)=0$

(b) $d_{1}^{*}(x, k)>0$, and

(c) $d_{2}^{*}(x, k)<0$.

The subscripts 1 and 2 denote the derivatives with respect to the first and second argument, respectively.

Part (a) of Proposition 1 follows because, for $x=0, E$ gets the entire dividend and, therefore, he has no reason to divert and possibly pay a fine. Part (b) follows because the higher the fraction of the cash flow rights in the hands of outside shareholders, the higher is the fraction of the next dollar diverted that $E$ avoids paying to them. That is, the marginal benefit of diverting is higher. Part (b) is the well-known Jensen and Meckling (1976) result that higher ownership concentration leads to more efficient actions. Burkart et al. (1998) and La Porta et al. (2002) derive similar results. Finally, part (c) follows because better investor protection (higher $k$ ) implies that diversion is more costly (the entrepreneur pays the fine more often) and less beneficial (the entrepreneur keeps the diverted amount less often). Expected diversion, $(1-k) d^{*} \Pi$, is also lower in environments with better investor protection. This is because diversion itself is lower (part (c)) and, in addition, the entrepreneur is forced to return the diverted amount to the firm more often.

Below, we show that the firm invests in the project the entire amount committed to it. This implies that, in this model, Tobin's Q is given by $\left(1-d^{*}(1-k)\right)(1+g)$. In addition, expected dividends divided by investment are given by $\left(1-d^{*}(1-k)\right)$ $(1+g)$, and divided by pre-expropriation cash flow by $\left(1-d^{*}(1-k)\right)$. Similarly, expected private benefits divided by investment are given by $d^{*}(1-k)(1+g)$, and divided by pre-theft cash flow by $d^{*}(1-k)$. The next result follows.

Corollary 1. Controlling for ownership concentration and growth opportunities, Tobin's $\mathrm{Q}$ and dividends are higher and private benefits lower in countries with better investor protection. 
These results are consistent with the findings in Claessens et al. (2002) and La Porta et al. (2002) for Tobin's Q, La Porta et al. (2000a, b) for dividends, and Nenova (1999) for private benefits - findings (4), (5), and (7) of the introduction.

The sensitivity of diversion to ownership concentration, $d_{1}^{*}$, plays an important role in the analysis. From assumption (d), it follows that $d_{1}^{*}$ does not decrease too fast. For the purposes of explaining the intuition of some of the results, however, we will say that $d_{1}^{*}$ is "relatively" constant. We explain in the appendix how this property guarantees a well-behaved maximization problem at date 1 . Here we explain how this property guarantees that $d_{1}^{*}$ is lower in countries with better investor protection.

Proposition 2. If assumptions (a)-(d) hold, then $d_{12}^{*}(x, k)<0$. The effect of a change in ownership concentration on the level of diversion is smaller in countries with better investor protection.

By Proposition 1, for two different levels of investor protection $k^{H}>k^{L}$, diversion is zero at $x=0$, and is lower for $k^{H}$ at all $x>0$. This is shown in the following figure:

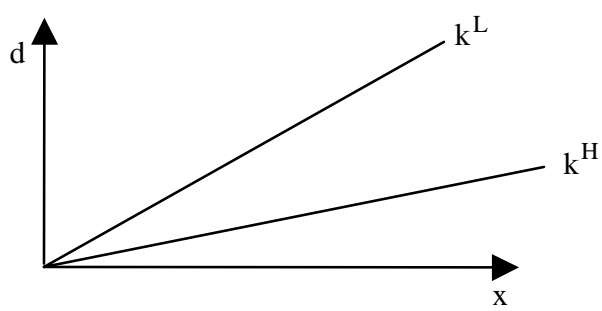

Proposition 2 states that, at any $x$, in addition to being below curve $k^{L}$, curve $k^{H}$ has a lower slope. Unlike Proposition 1, the proof of Proposition 2 requires assumption (d). Even without assumption (d), however, Proposition 2 must usually hold; otherwise, it would be impossible for curve $k^{H}$ to be always below curve $k^{L}$. In other words, even though we cannot derive Proposition 2 from assumptions (a)-(c), we can guarantee with these three assumptions that "on average" the slope of curve $k^{H}$ is smaller than that of curve $k^{L}$. If, in addition, the slopes are relatively constant (as assumption (d) guarantees) then the slope of curve $k^{H}$ is always smaller than that of curve $k^{L}$.

Proposition 2 predicts that, controlling for growth opportunities ( $g$ in this model), Tobin's Q, dividends, and private benefits are more sensitive to ownership concentration in countries with poor investor protection. La Porta et al. (2002) find support for the lower sensitivity of Tobin's Q to ownership concentration in countries with poor investor protection. We are not aware of similar evidence for dividends or private benefits.

At date $1, E$ chooses the size of the project, $I$, the amount of funds he contributes to the firm, $R_{E}$, and the fraction of the firm's cash flows he sells, $x$, by solving the 
following maximization problem:

$$
\max _{I, R_{E}, x}\left\{(1-x)\left(1-(1-k) d^{*}\right)+(1-k) d^{*}-k f\left(d^{*}\right)\right\} \Pi+(1+i)\left(W_{1}-R_{E}\right)
$$

such that

$$
R_{E} \leqslant W_{1},
$$

and

$$
I \leqslant R_{E}+R_{M}
$$

Letting $r(x, k)=x\left(1-(1-k) d^{*}(x, k)\right)$ be the fraction of the total revenue that outside shareholders expect to receive, $R_{M}$ can be written as

$$
R_{M}=\frac{r(x, k)}{1+i} \Pi \text {. }
$$

If the solution to the above problem is not to invest in the project $\left(I^{*}=0\right)$ and not to raise funds $\left(R_{M}^{*}=0\right)$, we say that the firm is not set up.

Proposition 3. At the solution to the entrepreneur's problem, the following hold

(a) If $g<i$, the firm is not set up.

(b) If $g=i$, the entrepreneur is indifferent between (1) not setting up the firm and (2) setting up the firm with no outside shareholders $\left(x^{*}=0\right)$ and investing any fraction of his wealth in the project.

(c) If $g>i$, the firm is set up and the solution can be of two types:

(1) If $\max _{x} r(x, k)(1+g) /(1+i) \geqslant 1$, the optimal $x^{*}$ is any of the (potentially many) $x$ that satisfy $r\left(x^{*}, k\right)(1+g) /(1+i) \geqslant 1$, and $I^{*}=+\infty$.

(2) If $\max _{x} r(x, k)(1+g) /(1+i)<1$, the entrepreneur invests all his wealth in the project and sets $R_{E}^{*}+R_{M}^{*}=I^{*}$. The optimal $x^{*}$ satisfies

$$
\frac{\partial}{\partial x}\left[k f\left(d^{*}\left(x^{*}, k\right)\right)\right]=r_{1}(x, k) \frac{\frac{1+g}{1+i}-1-k f\left(d^{*}\left(x^{*}, k\right)\right) \frac{1+g}{1+i}}{1-r\left(x^{*}, k\right) \frac{1+g}{1+i}},
$$

and $I^{*}=W_{1} /\left(1-r\left(x^{*}, k\right)(1+g) /(1+i)\right)$.

When $g<i$, the entrepreneur does not invest in the project since the market yields a higher rate of return. In addition, he does not raise funds from the market. At first, it seems that raising funds from the market, reinvesting them in the market, and then diverting a fraction of them is a beneficial action for the entrepreneur. However, with rational investors, an entrepreneur who raises funds pays for these funds in full and also incurs an additional cost due to the expected fine he pays. It is only beneficial to raise funds when they can be invested at a higher rate than they cost.

When $g=i$, the entrepreneur is indifferent between investing in the project or in the market and, as explained above, it is not beneficial for him to raise funds.

When $g>i$, it pays to raise funds from the market to invest them at this higher rate. The entrepreneur invests all his wealth and all the funds raised in the project since it yields a higher return than the market $\left(R_{E}^{*}+R_{M}^{*}=I^{*}\right)$. 
For each dollar invested, the entrepreneur collects $r(x, k)[(1+g) /(1+i)]$. In case (c)(1) of Proposition 3 there is an $x$ for which this expression is larger than one. The entrepreneur sets $x$ to such a value and raises more than one dollar per dollar invested. This allows him to invest any amount he wants. To maximize his wealth, he sets $I=+\infty$ and demands an infinite amount of funds. Obviously, the equilibrium never lies in this region. The interest rate rises to equate demand and supply.

However, when for all $x, r(x, k)[(1+g) /(1+i)]$ is less than one as in case $(c)(2)$, the entrepreneur has to contribute a fraction of each dollar invested from his wealth. Therefore, the size of the project is limited by his personal wealth. Using the fact that $R_{E}^{*}+R_{M}^{*}=I^{*}$, the objective function in Eq. (4) can be rewritten as

$$
\max _{x, I}\left[\frac{1+g}{1+i}-1-k f\left(d^{*}(x, k)\right) \frac{1+g}{1+i}\right] I+W_{1} .
$$

The expression $[(1+g) /(1+i)]-1$ is the NPV per dollar invested. Since investors demand the market interest rate $i$, the entrepreneur receives the entire NPV that the project generates. In addition, the entrepreneur pays the expected fine. The expression $k f\left(d^{*}\right)[(1+g) /(1+i)]$ is the present value of the expected fine per dollar invested. The entrepreneur faces the following tradeoff when choosing $x$. A higher $x$ leads to higher diversion and, therefore, a higher fine, but also allows $E$ to raise more funds and expand the size of the project. At the solution (Eq. (5)), the entrepreneur equates the marginal cost (left-hand side) with the marginal benefit (right-hand side). We explain in the appendix that assumption (d) guarantees a maximum for this problem.

The demand and supply of funds are derived directly from Proposition 3. Firm demand is downward sloping in the interest rate $i$. For a sufficiently large $i(>g)$, the firm is not set up and therefore demand is zero. For intermediate values of $i$, the firm is set up and its demand for funds is given by $R_{M}=\left[r\left(x^{*}, k\right) /(1+i)\right](1+g) I^{*}$. Over this range, as $i$ decreases, demand increases. Finally, for $i$ sufficiently low, the demand for funds is infinite. Since an individual firm's demand is downward sloping, so is aggregate demand.

The supply of funds from an entrepreneur is as follows. If the interest rate is higher than the productivity of his project $(i>g)$, the entrepreneur does not set up a firm and supplies his entire wealth to the market. If, however, the interest rate is below his project's productivity $(i<g)$, the entrepreneur invests his entire wealth in the project and does not supply funds to the market. In the case where $i=g$, the entrepreneur is indifferent between supplying any fraction of his wealth to the market and investing the rest in a wholly owned firm. Note that investor protection does not affect the supply of funds. Finally, the aggregate supply of funds is upward sloping. As the interest rate rises, more entrepreneurs find it profitable to supply their wealth to the market rather than setting up their own firms.

\section{Equilibrium}

We consider two cases. In Section 4.1, we assume perfect capital mobility across countries, and in Section 4.2 we assume no capital mobility. 


\subsection{Perfect capital mobility}

With perfect capital mobility, the world interest rate $i^{*}$ equates the world demand and supply for funds

$$
\sum_{c \in C} \sum_{j \in J} R_{M}^{j, c}=\sum_{c \in C} \sum_{j \in J}\left(W_{1}^{j, c}-R_{E}^{j, c}\right) .
$$

It can be shown that an equilibrium interest rate exists. At $i^{*}$, no entrepreneur will be in case (c)(1) of Proposition 3 because, in that case, the demand for funds is infinite.

Proposition 4. Consider two countries $H$ and $L$ that differ in the level of investor protection, with $k^{H}>k^{L}$. Country $H$ will have

(a) lower ownership concentration (for all j, $x^{* j, H}>x^{* j, L}$ ),

(b) larger external capital markets $\left(\sum_{j} R_{M}^{* j, H}>\sum_{j} R_{M}^{* j, L}\right)$, and

(c) larger firms (for all $j, I^{* j, H}>I^{* j, L}$ ).

These results correspond to findings (6), (1), and (3) from the introduction. Part (a) of Proposition 4 follows from the first-order condition in Eq. (5). This expression equates the marginal cost (left-hand side) and the marginal benefit (right-hand side) of selling an additional fraction of the cash flow rights (increasing $x$ ). The result that $x^{*}$ increases with investor protection follows because an increase in investor protection causes the marginal cost schedule to shift down and the marginal benefit schedule to shift up.

The marginal cost is the increase in the expected fine. It shifts down when investor protection increases because, with better investor protection, an increase in $x$ translates into a smaller increase in $d^{*}$ (Proposition 2), and consequently into a smaller increase in the expected fine.

The marginal benefit is the additional payoff obtained from investing the additional funds raised at a rate that is higher than the market rate. It shifts up when investor protection increases because more funds are raised by an increase in $x$ and the return on these funds is higher. An increase in $x$ has two effects on the amount raised: it increases the fraction of cash flow rights sold (quantity effect), but it reduces share prices (price effect) due to the increase in diversion. In countries with better investor protection, the effect of $x$ on diversion is lower, and hence the price reaction is smaller. Thus, more funds are raised. The numerator of the fraction that appears on the right-hand side of Eq. (5) is the return the entrepreneur receives for each dollar invested. We show in the appendix (see Lemma A.1) and discuss in Section 6 that this return is higher in countries with better investor protection.

Part (a) of Proposition 4 is consistent with previous empirical literature, such as La Porta et al. (1999) and Claessens et al. (2000). 
Part (b) is not as straightforward as it first appears. It is true that, in countries with better investor protection, firms sell more shares. But the size of the capital market is measured in dollars. Since lower concentration leads to lower prices, it is not a priori clear that countries with better investor protection have larger capital markets. The intuition for the result is as follows. As explained above, an increase in $x$ has two opposite effects on the amount raised: a quantity effect and a price effect. At the solution, it must be the case that the quantity effect dominates the price effect (i.e., the solution is in a region where the amount raised increases with $x$ ). If this were not the case, $E$ could increase his payoff by reducing $x$, because by doing so he would reduce the fine and also increase the amount raised. A higher equilibrium $x$ therefore implies larger capital markets. This result is consistent with La Porta et al. (1997).

Part (c) of Proposition 4 follows directly from the previous result. $E$ invests the sum of his own funds plus the amount he raises. The more he raises, the more he invests. This result is consistent with the findings of Kumar et al. (1999).

We now analyze the number of firms going public. In this model, an entrepreneur goes public (i.e., sells shares) as long as the return on assets, $g$, is larger than the interest rate, $i$. The reason is that no matter how poorly minority shareholders are protected, the costs due to diversion are initially very small and it always pays to sell at least a small fraction of the firm's cash flows. However, the situation changes if there is a small cost of going public, $c$, that the firm incurs. This cost can be interpreted as the listing costs, such as investment banking fees.

\section{Proposition 5. More firms go public in countries with better investor protection.}

Because the benefit of going public is larger in countries with better investor protection, there are more projects in such countries for which it is profitable to pay the cost to go public. This result is consistent with the evidence in La Porta et al. (1997) - finding (2) in the introduction.

This result reinforces those of Proposition 4. As a consequence of the direct cost of going public, some firms in countries with poor investor protection, which would have gone public absent this cost, stay private. They remain wholly owned by the entrepreneur and do not raise funds. The variation among countries in ownership concentration and the size of the capital market is larger with this cost than without it.

Finally, we analyze Tobin's Q, dividends, and private benefits of control under different levels of investor protection. In Corollary 1 we found that, controlling for ownership concentration, Tobin's Q and dividends are higher and private benefits lower in countries with better investor protection. This result is driven by the fact that, controlling for ownership, expected diversion is higher in countries with inferior investor protection (recall that Tobin's $\mathrm{Q}$ and dividends divided by investment are both given by $\left(1-(1-k) d^{*}\right)(1+g)$ and private benefits by $\left.(1-k) d^{*}(1+g)\right)$. Without controlling for ownership, the result is not as straightforward. 
The change in expected diversion, $(1-k) d^{*}$, when investor protection improves is given by

$$
\frac{\partial}{\partial k}\left[(1-k) d^{*}\left(x^{*}, k\right)\right]=-d^{*}\left(x^{*}, k\right)+(1-k)\left(d_{1}^{*}\left(x^{*}, k\right) \frac{\partial x^{*}}{\partial k}+d_{2}^{*}\left(x^{*}, k\right)\right) .
$$

An increase in investor protection implies that the entrepreneur keeps the diverted amount less often, thereby reducing expected diversion. This effect is captured by the first term. The rest of the expression represents the change in actual diversion. Recall that an increase in investor protection reduces ownership concentration. The second term represents the increase in diversion due to the decline in ownership concentration. Finally, an increase in investor protection discourages diversion, per part (c) of Proposition 1, and this effect is captured by the third term.

The first effect, the reduction in the probability of keeping the diverted amount, clearly reduces expected diversion. Therefore, a sufficient condition for the total effect to be negative is that actual diversion be decreasing in $k$. The following proposition lays out this sufficient condition.

Proposition 6. If $\partial\left[(1-k) x^{*} / k\right] / \partial k>0$ then $\partial\left[(1-k) d^{*}\left(x^{*}, k\right)\right] / \partial k<0$. That is, equilibrium diversion decreases as the level of investor protection rises.

The condition implies that the equilibrium level of $x$ changes slowly with investor protection. When this is the case, the increase in diversion due to the decline in ownership concentration is small compared to the decrease in diversion due to the disincentive effect of investor protection.

When Proposition 6 holds, countries with better investor protection have higher Tobin's Q, higher dividends, and lower private benefits of control, even though they have lower ownership concentration. These results correspond to findings (4), (5), and (7) of the introduction.

The condition in Proposition 6 is needed to ensure that the expected diversion monotonically decreases with the level of investor protection. However, without this condition, it is possible to show that for sufficiently high levels of investor protection, diversion is low. At the extreme, when $k=1$, the entrepreneur never keeps the diverted amount since he is always caught and pays the fine. He therefore does not divert regardless of the ownership structure. Thus, close to $k=1$ diversion is low.

\subsection{No capital mobility}

In this case, each country has its interest rate determined by its own supply and demand of funds. That is, for country $c$, the interest rate, $i^{c}$, is given by

$$
\sum_{j \in J} R_{M}^{j, c}=\sum_{j \in J}\left(W_{1}^{j, c}-R_{E}^{j, c}\right) .
$$

The following result can be established. 
Proposition 7. Consider two countries with different levels of investor protection. The country with better investor protection has a higher market interest rate.

The supply schedules in these two countries are the same (see Section 3). For any given interest rate, $i$, all the entrepreneurs with productivity of projects below the interest rate $(g<i)$ supply their funds to the market. This is true regardless of the level of investor protection.

The demand for external funds depends on the level of investor protection. All entrepreneurs with productivity of projects above the interest rate $i(g>i)$ set up projects. They invest their own wealth in the project and demand additional funds from the market. For a given interest rate, $i$, this additional demand is higher in countries with better investor protection. As a result, the interest rate is higher and the size of the external equity market is larger in countries with good investor protection.

Compared to the results derived for the case of perfect capital mobility, capital markets with no mobility are again larger and there is also more investment in countries with better investor protection, but the difference is smaller due to the effect of a higher interest rate. Also, ownership concentration is lower in countries with better investor protection, provided the supply of funds is not too steep. If the condition of Proposition 6 holds, then the results regarding the level of diversion, Tobin's Q, and dividends also hold in this setting. However, with closed capital markets, more firms go public in countries with good investor protection only when the cost of going public, $c$, is large.

Regardless of the level of investor protection, the entire wealth of the economy is invested at date 1 since there is no consumption at that date. However, in countries with better investor protection, a larger fraction of the invested capital comes from the external market and a smaller fraction from internal funds (the funds of the entrepreneurs setting up firms). To see this, suppose that the equilibrium interest rate in a country with poor investor protection is $i$. At this interest rate, there would be excess demand for funds in the country with better investor protection since, as explained above, the supply of external funds would be the same but the demand for external funds higher. To reach an equilibrium, the interest rate must increase. This increase raises the number of entrepreneurs supplying their funds to the market (hence larger external markets) and reduces the number of firms demanding funds (hence less use of internal funds).

An interesting corollary of Proposition 7 is the following.

Corollary 2. In countries with better investor protection, not only are more funds raised by firms, but these funds are also channeled to higher-productivity projects.

This result is consistent with the empirical results of Wurgler (2000) and corresponds to finding (8) of the introduction. This result holds since better investor protection leads high-productivity firms to demand more funds. The increased demand raises the country's interest rate. As a result, entrepreneurs with moderately productive projects supply their funds to the market in countries with good investor 
protection, but set up their own projects in countries with poor investor protection. As a consequence, in countries with good investor protection, funds concentrate in the high-productivity projects. This result does not hold in the case of perfect capital mobility since in that case the interest rate is independent of investor protection. However, the introduction of a moderate restriction on capital flows restores the result.

\section{Why doesn't capital flow to developing countries?}

One of the great puzzles in modern economics is why capital fails to flow from rich to poor countries (Lucas, 1990). ${ }^{4}$ Using a standard production technology, Lucas calculates that the implied marginal product of capital in India is 58 times that of the U.S. This result follows from the assumption of decreasing returns to scale and the fact that the U.S. has more capital. Lucas proposes three solutions to this puzzle: differences in human capital, external benefits of human capital, and capital market imperfections.

Proposition 7 suggests another possible explanation of the Lucas puzzle: better investor protection leading to higher interest rates and eliminating the incentive for capital to flow to a country with worse investor protection. In our model, total output is determined by the production technology and by agency costs (the waste or fines resulting from diversion). Even though firms in different countries have access to the same production technology, they differ in the severity of agency costs. In countries with better investor protection, the agency problem is less severe, so the effective production technology (net of agency costs) is more efficient. Countries with better investor protection then have a higher marginal product of capital and consequently higher interest rates.

But Proposition 7 is about countries with better investor protection, not richer countries. Since higher levels of wealth and capital might exert downward pressure on interest rates, the conclusion of Proposition 7 might not hold for richer countries. We show below, however, that even with the assumption that richer countries have better investor protection, it is still the case that they generally have higher interest rates.

We consider two countries, $H$ and $L$, with $k^{H}>k^{L}$. Whereas we assumed before that entrepreneurs with similar projects in different countries had the same wealth level, we now assume that entrepreneurs in the country with good investor protection $H$ are richer. That is, we assume that $g^{j, H}=g^{j, L}$ and $W^{j, H}=N W^{j, L}$, with $N>1$.

We solve for the case of no capital mobility. If the interest rate in the rich, goodinvestor-protection country is lower than that in the poor, bad-investor-protection country, then we expect capital to flow from the rich to the poor country. However, we find that, in this model, the equilibrium interest rate is not affected by the level of wealth in the economy.

\footnotetext{
${ }^{4}$ Henry (2000) finds a temporary increase in investment following a capital account liberalization. This flow, however, is small relative to the magnitude of the Lucas puzzle.
} 
Proposition 8. With no capital mobility, the equilibrium interest rate in country $H$ is independent of the level of wealth in the economy, $N$.

The marginal product of capital (interest rate) is affected by the severity of the agency problem. On the one hand, this problem is more severe in rich countries since, in equilibrium, more external funds need to be raised. On the other hand, the severity of the agency problem is mitigated in rich countries because richer entrepreneurs can afford to retain a larger fraction of the firm. These two effects cancel out as Proposition 8 indicates.

Since the equilibrium interest rate is independent of total wealth (i.e., $N$ ), only investor protection affects interest rates in this model. By Proposition 7, the interest rate is higher in the country with better investor protection. This theory, then, takes a further step toward explaining the Lucas puzzle of why capital does not flow from rich to poor countries: too much of it is expropriated by entrepreneurs in the latter.

\section{Who gains and who loses from an improvement in investor protection?}

Why don't the countries suffering from financial underdevelopment improve their levels of investor protection? Recent research suggests that political opposition to reform from incumbent entrepreneurs is an important part of the answer (Bebchuk and Roe, 1999; La Porta et al., 2000b; Hellwig, 2000; Rajan and Zingales, 2001). In addition, Rajan and Zingales (2001) show that open economies are more likely to undertake reforms benefiting financial development. Our model enables us to examine who gains and who loses from improvements in investor protection. It therefore sheds light on both the question of opposition to reform and the dependence of such opposition on openness.

If we focus attention on firms that have been already set up, it is clear that entrepreneurs that set up firms lose and investors (i.e., those entrepreneurs who do not set up firms but instead invest in the market) gain from an improvement in investor protection. The reason is that the price paid by investors for a firm's shares incorporates expectations of high diversion by the entrepreneur. When investor protection is unexpectedly improved, the entrepreneur diverts less and loses as a result. Investors gain since lower diversion implies higher dividends.

But do entrepreneurs lose more in countries that are open or in countries that restrict capital flows? To answer this question, we focus on a country that initially has poor investor protection (relative to the world average), but unexpectedly improves it after the firms in the country have been set up. We compare the losses of entrepreneurs and the gains to investors from this improvement under the alternative assumptions about openness.

Proposition 9. Consider a small country (sufficiently small to have no effect on the world interest rate) with a low level of investor protection, which unexpectedly improves the level of investor protection after its firms have been set up. In a country initially 
open to capital flows, entrepreneurs suffer less from this improvement than they do in a country that initially restricts capital flows.

To understand the intuition for the welfare effect on entrepreneurs, we first need to analyze the ownership choices and the amount of diversion under perfect capital mobility and no capital mobility. The country has a lower interest rate when it restricts capital flows than when it does not. This is because, as we showed in Proposition 7, poor investor protection puts downward pressure on the interest rate in a closed economy. In contrast, when the country is open to world capital flows, it has the world interest rate, which is higher. A lower interest rate implies that ownership is less concentrated (i.e., $x$ is higher) because entrepreneurs sell more shares as investors demand a lower return. In sum, firms in a country that is closed to capital flows have lower ownership concentration and consequently higher diversion.

An improvement in investor protection has two effects on the entrepreneur's payoff. An increase in the probability of being caught has a direct effect on his payoff since the entrepreneur keeps the diverted amount less often and pays the fine more often. The entrepreneur therefore suffers more in situations where he was initially diverting more (he is forced to return a larger amount and in addition he is more likely to pay a higher fine). There is also an indirect effect on the entrepreneur's payoff since an improvement in investor protection reduces the level of diversion. However, by the envelope theorem this effect is small since the entrepreneur chooses diversion optimally at date 2 . Overall, entrepreneurs suffer more when the country is initially closed to capital flows since, as we explained above, diversion is higher in that scenario.

In Proposition 9, we assume that firms have already been set up. We can also look at this issue from the perspective of entrepreneurs about to set up firms. After all, even existing entrepreneurs often need new capital for new projects. To focus on this issue, we consider the consequences of an improvement in investor protection before firms are set up.

Proposition 10. Suppose investor protection is improved before any firm is set up.

(a) In the case of perfect capital mobility, all the entrepreneurs setting up firms are strictly better off.

(b) In the case of no capital mobility, there is a group of entrepreneurs (those with marginally profitable projects) who are made worse off.

In the case of perfect capital mobility, the improvement in investor protection does not affect the interest rate. This implies that the same group of firms is set up. Entrepreneurs who set up their firms benefit because they raise more funds and pay lower fines.

Entrepreneurs raise more funds because investors anticipate less diversion and so are willing to pay higher prices for the shares. The fact that entrepreneurs pay lower fines is not a priori clear. On the one hand, an improvement in investor protection increases the expected fine since entrepreneurs are more likely to be caught (direct 
effect). On the other hand, entrepreneurs divert less (incentive effect), and consequently pay a smaller fine when caught. To understand why the expected fine is smaller in countries with better investor protection, compare the increase in the expected fine - not the total expected fine - as more shares are sold, $\partial\left[k f\left(d^{*}\right)\right] / \partial x$. This increase is given by $k f^{\prime}\left(d^{*}\right) \cdot d_{1}^{*}$ - the marginal cost of diverting times the increase in diversion. The increase in diversion is higher in countries with poor investor protection, since by Proposition $2, d_{12}^{*}<0$. In addition, the marginal cost of diverting is also higher in countries with poor investor protection since, at date 2 , the entrepreneur equates $k f^{\prime}(d)$ with $(1-k) x$ and this last expression is higher for smaller $k$. Since $\partial\left[k f\left(d^{*}\right)\right] / \partial x$ is higher in countries with poor investor protection at all levels of ownership concentration, the total expected fine, $k f\left(d^{*}\right)$, is higher as well.

The situation is different when the country is closed to world capital flows. In this case, in addition to the effects discussed above, the equilibrium interest rate increases (Proposition 7). As a result, entrepreneurs with marginally profitable projects who were taking advantage of the low interest rate are no longer able to set up their firms.

The welfare effects of an improvement in investor protection cannot be analyzed in a partial equilibrium setting since the behavior of the equilibrium interest rate is crucial for the analysis. The conclusion of Propositions 9 and 10 is that entrepreneurs are more strongly opposed to an improvement of investor protection when the country restricts the flows of capital. These propositions predict that capital market openness is more likely to politically accommodate improvements in investor protection and capital market development, consistent with the recent evidence of Rajan and Zingales (2001).

\section{Conclusion}

In this paper, we present a very basic model of an entrepreneur going public in an environment with poor legal protection of outside shareholders. We examine this entrepreneur's decisions and the market equilibrium. The model clarifies a number of assumptions needed to obtain empirically valid predictions on corporate ownership patterns, dividend policies, firm valuation, and financial development in the regimes of poor investor protection. Under these assumptions, the model is consistent with the basic empirical regularities concerning the relation between investor protection and corporate finance. In addition, the model makes a number of general equilibrium predictions concerning the patterns of capital flows among countries, as well as the politics of corporate governance reform. These predictions appear to be consistent with recently developed empirical evidence.

\section{Appendix}

Proof of Proposition 1. Part (a) follows because by assumption (b), $f^{\prime}(0)=0$. Part (b) follows by completely differentiating Eq. (3) with respect to $x$ to obtain 
$d_{1}^{*}(x, k)=\frac{1}{[k /(1-k)] f^{\prime \prime}\left(d^{*}\right)}>0$. Similarly, part (c) follows by completely differentiating Eq. (3) with respect to $k$ to obtain $d_{2}^{*}(x, k)=-\left[x / k^{2} f^{\prime \prime}\left(d^{*}\right)\right]<0$.

Proof of Proposition 2.

$$
d_{12}^{*}=\frac{-1}{k^{2} f^{\prime \prime}(d)}\left[1-\frac{f^{\prime \prime \prime}(d) f^{\prime}(d)}{\left(f^{\prime \prime}(d)\right)^{2}}\right]
$$

Note that

$$
\frac{\partial}{\partial d}\left[\frac{f^{\prime}(d)}{f^{\prime \prime}(d)}\right]=1-\frac{f^{\prime \prime \prime}(d) f^{\prime}(d)}{\left(f^{\prime \prime}(d)\right)^{2}}>0 \quad \text { (by assumption (d)). }
$$

Therefore $d_{12}^{*}<0$.

Proof of Proposition 3. We first solve for $\Pi$ and $R_{M}$ (note that, in the text, each is defined as a function of the other) to obtain

$$
\Pi=\frac{(g-i) I+(1+i) R_{E}}{1-r(x, k)}
$$

and

$$
R_{M}=\frac{r(x, k)}{1+i} \cdot \frac{(g-i) I+(1+i) R_{E}}{1-r(x, k)} .
$$

Using these expressions, the entrepreneur's problem in Eq. (4) can be written as

$$
\max _{I, R_{E}, x}\left\{1-r(x, k)-k f\left(d^{*}\right)\right\} \frac{(g-i) I+(1+i) R_{E}}{1-r(x, k)}+(1+i)\left(W_{1}-R_{E}\right)
$$

subject to

$$
R_{E} \leqslant W_{1}
$$

and

$$
R_{E} \geqslant I\left[1-r(x, k) \frac{1+g}{1+i}\right]
$$

where the last inequality is equivalent to $R_{E}+R_{M} \geqslant I$.

First, consider the case where $g<i$. Since $g-i<0$, the objective function is decreasing in $I$. Since (A.3) is satisfied for $I^{*}=0$, it is optimal to set $I^{*}=0$. Now, if $x^{*}=0$, then $R_{M}^{*}=0$. So suppose $x^{*}>0$. This implies that $k f\left(d^{*}\right)>0$ and hence $(1-r-k f) /(1-r)<1$. Therefore setting $R_{E}^{*}=0$ maximizes the objective function. In addition, both (A.2) and (A.3) are satisfied for $R_{E}^{*}=0$ and $I^{*}=0$. Finally, for these values, $R_{M}^{*}=0$.

Second, consider the case where $g=i$. If $x=0$, the objective function reduces to $(1+i) W_{1}$, and $R_{M}=0$. In this case $R_{E}$ and $I$ can be set to any value that satisfies the constraint. If, however, $x>0$, then $[(1-r-k f) /(1-r)]<1$ and therefore $R_{E}=0$ maximizes the objective function. Since $I$ does not affect the objective function, it can be set to any value that satisfies (A.3); in this case, the only possible value is 
$I=0$. Note that, in this case, the objective function also reduces to $(1+i) W_{1}$, and that $R_{M}=0$.

Finally, consider the case where $g>i$. In this case, the objective function is increasing in $I$. Therefore, in subcase (1), $x^{*}$ is such that $r\left(x^{*}, k\right)[(1+g) /(1+i)] \geqslant 1$ and $I^{*}=+\infty$. For these values, the constraints are satisfied and the objective function is maximized.

Consider subcase (2). We show that both constraints bind. First, suppose that, at the solution, $R_{E}^{*}>I^{*}\left[1-r\left(x^{*}, k\right)[(1+g) /(1+i)]\right]$. Since the constraint is not binding, $I$ can be increased, thereby increasing the objective function (contradiction).

Now, since (A.3) binds, Eq. (A.1) can be written as

$$
\max _{x, I}\left[\frac{1+g}{1+i}-1-k f\left(d^{*}(x, k)\right) \frac{1+g}{1+i}\right] I+W_{1}
$$

and constraint (A.2) as

$$
I \leqslant \frac{W_{1}}{1-r(x, k) \frac{1+g}{1+i}} .
$$

At the solution, the entrepreneur sets $x$ such that the expression in brackets in $\left(\mathrm{A} .1^{\prime}\right)$ is positive (this expression is positive for $x=0$, and therefore, it must be positive at the solution) and therefore, he sets $I$ as high as possible. That is, constraint (A.2) binds, which means that the entrepreneur invests his entire wealth in the project. Plugging the value of $I$ into Eq. (A.1') and letting

$$
G(x, k)=\frac{\frac{1+g}{1+i}-1-k f\left(d^{*}(x, k)\right) \frac{1+g}{1+i}}{1-r(x, k) \frac{1+g}{1+i}},
$$

the problem reduces to $\max _{x} G(x, k)$. The first-order condition of this problem, $G_{1}\left(x^{*}, k\right)=0$, is Eq. (5). Finally, we show that the second-order condition for a maximum hold. Letting

$$
\begin{gathered}
M=\frac{\frac{1+g}{1+i}}{1-\frac{1+g}{1+i} r\left(x^{*}, k\right)}>0, \\
G_{11}\left(x^{*}, k\right)=M\left(-(1-k) d_{1}^{*}\left(x^{*}, k\right)-(1-k) x^{*} d_{11}^{*}\left(x^{*}, k\right)+r_{11}\left(x^{*}, k\right) G\left(x^{*}, k\right)\right) \\
G_{11}\left(x^{*}, k\right)=-M(1-k) d_{1}^{*}\left[\left(2-\frac{f^{\prime}(d) f^{\prime \prime \prime}(d)}{\left(f^{\prime \prime}(d)\right)^{2}}\right) G\left(x^{*}, k\right)\right. \\
\left.+\left(1-\frac{f^{\prime}(d) f^{\prime \prime \prime}(d)}{\left(f^{\prime \prime}(d)\right)^{2}}\right)\right]<0,
\end{gathered}
$$

where both parentheses are positive by assumption (d).

Assumption (d) guarantees that the problem has a maximum. Roughly speaking this assumption guarantees that the marginal cost is increasing and the marginal benefit decreasing, a sufficient condition for the solution of (5) to be a maximum. The marginal cost is the increase in the expected fine as a result of an increase $x$. This increase is given by $k f^{\prime}\left(d^{*}\right) \cdot d_{1}^{*}$. By assumption (d), $d_{1}^{*}$ is relatively constant throughout the ownership range. Also, at date 2, the entrepreneur equates the 
increase in the expected fine due to a change in diversion, $k f^{\prime}\left(d^{*}\right)$, with the increase in expected dividend savings $(1-k) x$, which is increasing in $x$. Therefore, the marginal cost, $k f^{\prime}\left(d^{*}\right) \cdot d_{1}^{*}$, is increasing in $x$.

The marginal benefit is given by the higher-than-market return that the additional funds raised provide. The additional revenue raised is given by $r_{1}(x, k)=[1-(1-$ $\left.k) d^{*}\right]+\left[-x(1-k) d_{1}^{*}\right]$. The first bracket (quantity effect) is the price the market pays for the additional unit sold. For high values of $x$, the market expects higher diversion and hence pays a lower price for the additional unit sold. That is, the quantity effect is decreasing in $x$. When an additional share is sold, the price declines since the market expects more diversion. The second bracket (the price effect) is the negative effect on revenue that the price decline has on all the units sold. Since by assumption (d), $d_{1}^{*}$ is relatively constant, the price decline is relatively constant. However, since at higher levels of $x$, this price decline affects more units, the price effect is larger for higher $x$. In sum, as $x$ increases, the positive quantity effect decreases and the negative price effect increases. Therefore, the additional revenue and hence the marginal benefit are decreasing in $x$.

Lemma A.1. $\partial\left[k f\left(d^{*}(x, k)\right)\right] / \partial k<0$.

Proof.

$$
\begin{aligned}
\frac{\partial}{\partial k}\left[k f\left(d^{*}(x, k)\right)\right] & =\frac{\partial}{\partial k}\left[k f\left(d^{*}(0, k)\right)+k \int_{0}^{x} f^{\prime}\left(d^{*}(h, k)\right) d_{1}^{*}(h, k) \mathrm{d} h\right] \\
& =\frac{\partial}{\partial k} \int_{0}^{x} h(1-k) d_{1}^{*}(h, k) \mathrm{d} h \\
& =\int_{0}^{x} h \frac{\partial}{\partial k}\left[(1-k) d_{1}^{*}(h, k)\right] \mathrm{d} h<0 .
\end{aligned}
$$

The second line follows from $d^{*}(0, k)=0$ (part (a) of Proposition 1$), f(0)=0$ (assumption (a)), and by replacing $f^{\prime}\left(d^{*}(h, k)\right)$ from the first-order condition in Eq. (3). The last inequality follows from Proposition 2.

Proof of Proposition 4. Part (a). Suppose $g>i$. Completely differentiating the firstorder condition with respect to $k$ leads to

$$
\frac{\partial x^{*}}{\partial k}=-\frac{G_{12}\left(x^{*}, k\right)}{G_{11}\left(x^{*}, k\right)}=-\left.\frac{M\left(-x \frac{\partial}{\partial k}\left[(1-k) d_{1}\right]+r_{12} G+r_{1} G_{2}\right)}{G_{11}}\right|_{x=x^{*}} .
$$

We need to show that the above expression is positive. By the second-order condition, $G_{11}\left(x^{*}, k\right)<0$. As stated above, $M>0$. The first term in the numerator is positive since, by Proposition $2, d_{12}^{*}<0$. The second term is the product of two positive expressions. First, $G(0, k)>0$, and therefore, $G\left(x^{*}, k\right)>0$. Second, $r_{12}=$ $-\partial\left[(1-k) d^{*}\right] / \partial k-x \partial\left[(1-k) d_{1}^{*}\right] / \partial k>0$ because the two terms in the first bracket decrease with $k$, and, by Proposition 2, $d_{12}^{*}<0$. Finally, the third term in the numerator is also the product of two positive numbers. $r_{1}\left(x^{*}, k\right)>0$ since, as we explained in the text, the solution must in a region where the amount collected is 
increasing in $x$. Also $G_{2}\left(x^{*}, k\right)=M\left(k_{2} g-\partial\left[k f\left(d^{*}\right)\right] / \partial k\right)>0$ because $r_{2}=x(d-(1-$ $\left.k) d_{2}\right)>0\left(d_{2}<0\right.$ by part (c) of Proposition 1) and the second term is negative by Lemma A.1.

Part (b) Each firm raises

$$
R_{M}=\frac{r\left(x^{*}, k\right)}{1+i}(1+g) I^{*}=\frac{r\left(x^{*}, k\right)}{1+i}(1+g) \frac{W_{1}}{1-r\left(x^{*}, k\right) \frac{1+g}{1+i}}
$$

This expression is increasing in $r\left(x^{*}, k\right)$. And $\partial r\left(x^{*}, k\right) / \partial k=r_{1}\left(x^{*}, k\right)\left(\partial x^{*} / \partial k\right)+$ $r_{2}\left(x^{*}, k\right)>0$, because (1) $\partial x^{*} / \partial k>0$ by part (a), (2) $r_{1}\left(x^{*}, k\right)>0$, and (3) $r_{2}\left(x^{*}, k\right)>0$ as explained in the proof of part (a). Since this is true for every firm $j$, it is also true for the aggregate.

Part (c) $E$ invests in assets the amount he raises in the market plus his entire wealth. Since he raises more for higher $k$, the result follows.

Proof of Proposition 5. By going public, $E$ gets $G\left(x^{*}, k\right) W_{1}+W_{1}-c$, and by staying private, $E$ gets $[(1+g) /(1+i)] W_{1}$. By the envelope theorem, $\partial G\left(x^{*}, k\right) / \partial k=$ $G_{2}\left(x^{*}, k\right)$. This expression is positive as explained in part (a) of the proof of Proposition 4 . Therefore, the difference between going public and staying private is increasing in $k$. That is, in countries with good investor protection, the $g$ required for the gains of going public to outweigh the cost $c$ is lower.

Proof of Proposition 6. Let $x^{*}(k)$ be the equilibrium level of $x$ for any firm $j$ when the country's level of investor protection is $k$. By Eq. (3), the equilibrium level of diversion solves $f^{\prime}\left(d^{*}\right)=[(1-k) / k] x^{*}(k)$. Since $f^{\prime \prime}>0$, the higher the right-hand side, the higher is the level of diversion. Therefore, diversion is decreasing in $k$ if and only if $\partial\left[(1-k) x^{*}(k) / k\right] / \partial k<0$.

Proof of Proposition 7. As explained in Section 3, the supply of funds is independent of the degree of investor protection. In addition, as explained in part (b) of the proof of Proposition 4, for a given $i$, demand is higher in countries with good investor protection. The result follows.

Proof of Proposition 8. In an economy closed to capital flows, the equilibrium level of interest rate, $i^{c}$, solves

$$
\sum_{j \mathrm{st} g^{j} \leqslant i^{c}} N W^{j}=\sum_{j \mathrm{st} g^{j}>i^{c}}\left(\frac{N W^{j}}{1-r\left(x^{* j}, k\right) \frac{1+g^{j}}{1+i^{c}}}-N W^{j}\right),
$$

where the left-hand side is the supply of funds (all entrepreneurs with projects with productivity less than $i^{c}$ supply their entire wealth) and the right-hand side is the demand for funds (for each firm set up, it is investment minus the entrepreneur's wealth). Since the optimal $x^{* j}$ is independent of the entrepreneur's wealth (see 
Eq. (5)), it can be seen from the above equation that the equilibrium interest rate is independent of $N$.

Proof of Proposition 9. The country we consider is small (so that whether it is open or closed to capital markets does not affect the world interest rate) and has investor protection of $k$. We consider the world as a country with investor protection of $k^{w}>k$. We let $i^{w}$ be the world interest rate and $i^{c}$ be the interest rate that prevails in the country when it is closed to capital markets. By Proposition $7, i^{w}>i^{c}$.

Consider an entrepreneur $j$ with a project with productivity $g^{j}$, with $g^{j}>i^{w}>i^{c}$ (i.e., this entrepreneur sets up his firm both when the country is open and when it restricts capital flows). We let $x^{w, j}$ and $x^{c, j}$ be the optimal ownership concentration when the country is open to capital flows and when it is closed, respectively. Letting $m=(1+g) /(1+i)$ and by completely differentiating the first-order condition $G_{1}\left(x^{*}, k\right)=0$ with respect to $i$, we obtain

$$
\begin{aligned}
\frac{\partial x^{*}}{\partial i} & =-\frac{\frac{\partial G_{1}\left(x^{*}, k\right)}{\partial i}}{G_{11}\left(x^{*}, k\right)} \\
& =-\left.\frac{M r_{1} \frac{1}{1-r m}\left[\left(1-k f\left(d^{*}\right)\right)(1-r m)+r\left(m-1-m k f\left(d^{*}\right)\right)\right] \frac{\partial m}{\partial i}}{G_{11}}\right|_{x=x^{*}}<0 .
\end{aligned}
$$

This inequality follows because $1-r\left(x^{*}, k\right) m>0$ (we discussed this condition after Proposition 3). In addition, since $G\left(x^{*}, k\right)>0$, then $m-1-m k f\left(d^{*}\right)>0$, and this last inequality implies that $1-k f(d *)>0$. Also, $\partial m / \partial i<0$. The sign of all other expressions were discussed in the above proofs. It follows from the above derivative that $x^{w, j}<x^{c, j}$.

The marginal increase in payoffs of an entrepreneur due to a change in investor protection is given by

$$
\begin{aligned}
& \frac{\partial}{\partial k}\left\{(1-x)\left(1-(1-k) d^{*}\right)+(1-k) d^{*}-k f\left(d^{*}\right)\right\}(1+g) I^{*} \\
& \quad=-\left\{x d^{*}+f\left(d^{*}\right)\right\}(1+g) I^{*}
\end{aligned}
$$

where we have used the envelope theorem since the entrepreneur chooses $d^{*}$ optimally after the change in investor protection. We show that this loss is larger when the country is closed to capital flows. First, $x^{w, j} d^{*}\left(x^{w, j}, k\right)+$ $f\left(d\left(x^{w, j}, k\right)\right)<x^{c, j} d^{*}\left(x^{c, j}, k\right)+f\left(d\left(x^{c, j}, k\right)\right)$ since $x^{w, j}<x^{c, j}, d_{1}^{*}>0$, and $f^{\prime}>0$. In addition, $I^{*}$, which is given by

$$
I^{*}=W_{1} /\left(1-r\left(x^{*}, k\right) \frac{1+g}{1+i}\right),
$$

is higher in the closed economy. This follows from the fact that, at the solution, $r(x, k)$ is increasing in $x, x^{w, j}<x^{c, j}$, and $i^{w}>i^{c}$. 
Finally we compare the aggregate losses of entrepreneurs in both scenarios:

$$
\begin{aligned}
\sum_{j: g^{j} \geqslant i^{c}}\left\{x^{c, j} d^{*}\left(x^{c, j}, k\right)+f\left(d^{*}\left(x^{c, j}, k\right)\right)\right\}\left(1+g^{j}\right) I^{c, j} \\
=\sum_{j: g^{j} \geqslant i^{w}}\left\{x^{c, j} d^{*}\left(x^{c, j}, k\right)+f\left(d^{*}\left(x^{c, j}, k\right)\right)\right\}\left(1+g^{j}\right) I^{c, j} \\
\quad+\sum_{j: i^{w>g^{j}} \geqslant i^{c}}\left\{x^{c, j} d^{*}\left(x^{c, j}, k\right)+f\left(d^{*}\left(x^{c, j}, k\right)\right)\right\}\left(1+g^{j}\right) I^{c, j} \\
\geqslant \sum_{j: g^{j} \geqslant i^{w}}\left\{x^{w, j} d^{*}\left(x^{w, j}, k\right)+f\left(d^{*}\left(x^{w, j}, k\right)\right)\right\}\left(1+g^{j}\right) I^{w, j}
\end{aligned}
$$

where the first expression is the aggregate loss of entrepreneurs setting up firms in a country closed to capital flows and the last expression is a similar expression for a country that is open to capital flows. The equality follows because $i^{w}>i^{c}$. The inequality follows from the above discussion and the fact that losses are positive.

Proof of Proposition 10. (1) From Eqs. (A.1') and (A.2'), the entrepreneur's problem at date 1 is given by

$$
\max _{x, I}\left[\frac{1+g}{1+i}-1-k f\left(d^{*}(x, k)\right) \frac{1+g}{1+i}\right] I+W_{1}
$$

subject to

$$
I \leqslant \frac{W_{1}}{1-r(x, k) \frac{1+g}{1+i}}
$$

An improvement in investor protection raises the payoff function for any given $x$ since, by Lemma A.1, $\partial\left[k f\left(d^{*}(x, k)\right)\right] / \partial k<0$. In addition, an increase in investor protection relaxes the constraint since $r_{2}(x, k)>0$. Therefore, each entrepreneur that sets up a firm is better off.

(2) Consider a country closed to capital flows. The interest rate is initially $i^{c}$ and rises to $i^{c}+\varepsilon$ when investor protection improves $(\varepsilon>0$ by Proposition 7$)$. Consider an entrepreneur with a project of productivity $g=i^{c}+\varepsilon$. We show that this entrepreneur is strictly worse off from an improvement in investor protection. If there is such an improvement, he is indifferent between setting up and keeping 100\% of its shares or supplying his funds to the market (by Proposition 3). His payoff is then $W_{1}(1+g)$. If there is no improvement, the interest rate is $i^{c}$. The entrepreneur can always invest in his project, keep $100 \%$ of the equity, and obtain a payoff of $W_{1}(1+g)$. However, by Proposition 3, since $g>i^{c}$, keeping $100 \%$ of the equity is not optimal. He can do better by setting up the firm and selling some positive fraction of the equity. Therefore, his payoff in this scenario is higher than $W_{1}(1+g)$.

\section{References}

Bebchuk, L., 1999. The rent protection theory of corporate ownership and control. Unpublished working paper, Harvard Law School, Cambridge, MA. 
Bebchuk, L., Roe, M., 1999. A theory of path dependence in corporate ownership and governance. Stanford Law Review 52, 127-270.

Becker, G.S., 1968. Crime and punishment: an economic approach. Journal of Political Economy 76, 169-217.

Bennedsen, M., Wolfenzon, D., 2000. The balance of power in closely held corporations. Journal of Financial Economics 58, 113-139.

Burkart, M., Gromb, D., Panunzi, F., 1997. Large shareholders, monitoring, and fiduciary duty. Quarterly Journal of Economics 112, 693-728.

Burkart, M., Gromb, D., Panunzi, F., 1998. Why higher takeover premia protect minority shareholders. Journal of Political Economy 106, 172-204.

Carlin, W., Mayer, C., 1999. Finance, investment and growth. Unpublished working paper, University College, London.

Claessens, S., Djankov, S., Lang, L., 2000. The separation of ownership and control in East Asian corporations. Journal of Financial Economics 58, 81-112.

Claessens, S., Djankov, S., Fan, J., Lang, L., 2002. Disentangling the incentive and entrenchment effects of large shareholdings. Journal of Finance 57, 2379-2408.

Demirguc-Kunt, A., Maksimovic, V., 1998. Law, finance, and firm growth. Journal of Finance 53, $2107-2139$.

European Corporate Governance Network (ECGN), 1997. The Separation of Ownership and Control: A Survey of 7 European Countries Preliminary Report to the European Commission, Vols. 1-4. European Corporate Governance Network, Brussels.

Friedman, E., Johnson, S., 2000. Tunneling and propping. Unpublished manuscript, Massachusetts Institute of Technology, Cambridge, MA.

Grossman, S., Hart, O., 1988. One-share-one vote and the market for corporate control. Journal of Financial Economics 20, 175-202.

Harris, M., Raviv, A., 1988. Corporate governance: voting rights and majority rules. Journal of Financial Economics 20, 203-236.

Hart, O., 1995. Firms, Contracts, and Financial Structure. Oxford University Press, London.

Hellwig, M., 2000. On the economics and politics of corporate finance and corporate control. In: Vives, X. (Ed.), Corporate Governance: Theoretical and Empirical Perspectives. Cambridge University Press, Cambridge, UK.

Henry, P., 2000. Do stock market liberalizations cause investment booms? Journal of Financial Economics $58,301-334$.

Jensen, M., Meckling, W., 1976. Theory of the firm: managerial behavior, agency costs, and ownership structure. Journal of Financial Economics 3, 305-360.

Johnson, S., La Porta, R., Lopez-de-Silanes, F., Shleifer, A., 2000. Tunneling. American Economic Review Papers and Proceedings 90, 22-27.

Kumar, K., Rajan, R., Zingales, L., 1999. What determines firm size? NBER Working Paper 7208, National Bureau of Economic Research, Cambridge, MA.

La Porta, R., Lopez-de-Silanes, F., Shleifer, A., Vishny, R., 1997. Legal determinants of external finance. Journal of Finance 52, 1131-1150.

La Porta, R., Lopez-de-Silanes, F., Shleifer, A., Vishny, R., 1998. Law and finance. Journal of Political Economy 106, 1113-1155.

La Porta, R., Lopez-de-Silanes, F., Shleifer, A., 1999. Corporate ownership around the world. Journal of Finance 54, 471-517.

La Porta, R., Lopez-de-Silanes, F., Shleifer, A., Vishny, R., 2000a. Agency problems and dividend policies around the world. Journal of Finance 55, 1-33.

La Porta, R., Lopez-de-Silanes, F., Shleifer, A., Vishny, R., 2000b. Investor protection and corporate governance. Journal of Financial Economics 58, 3-27.

La Porta, R., Lopez-de-Silanes, F., Shleifer, A., Vishny, R., 2002. Investor protection and corporate valuation. Journal of Finance 57, 1147-1170.

Levine, R., Zervos, S., 1998. Stock markets, banks and economic growth. American Economic Review 88, $537-558$. 
Lucas, R., 1990. Why doesn't capital flow from rich to poor countries? American Economic Review Papers and Proceedings 80, 92-96.

Nenova, T., 1999. The value of a corporate vote and private benefits: a cross-country analysis. Unpublished working paper, Harvard University, Cambridge, MA.

Pagano, M., Roel, A., 1998. The choice of stock ownership structure: agency costs, monitoring, and the decision to go public. Quarterly Journal of Economics 113, 187-225.

Rajan, R., Zingales, L., 1998. Financial dependence and growth. American Economic Review 88, 559-586.

Rajan, R., Zingales, L., 2001. The great reversals: the politics of financial development in the 20th century. NBER Working Paper 8178, National Bureau of Economic Research, Cambridge, MA.

Shleifer, A., Vishny, R., 1997. A survey of corporate governance. Journal of Finance 52, 737-783.

Wolfenzon, D., 1999. A theory of pyramidal ownership. Unpublished working paper, Harvard University, Cambridge, MA.

Wurgler, J., 2000. Financial markets and the allocation of capital. Journal of Financial Economics 58, $187-214$.

Zingales, L., 1994. The value of the voting right: a study of the Milan stock exchange. The Review of Financial Studies 7, 125-148.

Zingales, L., 1995. Inside ownership and the decision to go public. Review of Economic Studies 62, 425-448. 